\title{
Bioengineering options and strategies for the optimisation of anaerobic digestion processes
}

Robert Michael William Ferguson, Raffaella Villa*, Frédéric Coulon

Department of Environmental Science and Technology, School of Applied Sciences, Cranfield University, Cranfield, UK

Canfield University, Cranfield, MK43 0AL.

E: r.villa@cranfield.ac.uk T: +44 (0)1234 750111 ext. 2320

E: f.coulon@cranfield.ac.uk T: +44 (0)1234 754981

E: r.ferguson@cranfield.ac.uk T: +44 (0)1234 750111

*corresponding author:

Robert Ferguson was funded by an EPSRC CASE Award supported by the QUESTOR partnership (CRA1/09/12) 


\section{Bioengineering options and strategies for the optimisation of anaerobic digestion processes}

Anaerobic digestion (AD) is a complex biological process and the microbial diversity and dynamics within the reactor needs to be understood and considered when process optimisation is sought after. Microbial interactions such as competition, mutualism, antagonism and syntrophism affect the function and the survival of single species in the community; hence they need to be understood for process improvement. Although the relationship between process performance and microbial community structure is well established, changes in the community might occur without detectable changes in gas production and reactor performance. Recent molecular based studies have highlighted the complexity of $\mathrm{AD}$ systems revealing the presence of several uncultivated species and the need for further research in this area. However, this information is still rarely used for process optimisation. The integration of next generation sequencing technologies, such as 454-pyrosequencing, with other techniques, such as phospholipid-derived fatty acids analysis can provide an holistic understanding of the microbial community. In addition, the in depth phylogenetic resolution provided can aid environmental ecologists and engineers to better understand and optimise AD process and consolidate the information collected to date.

Keywords: Anaerobic digestion; microbial diversity; process optimisation; bioaugmentation; microbial ecology.

\section{Introduction}

Anaerobic Digestion (AD) is the biological conversion, in the absence of oxygen, of organic waste into biogas (comprising methane and carbon dioxide). The AD process is an attractive waste management strategy as it has a number of useful outputs, including biogas, heat and digestate [1-4]. The use of the anaerobic process to treat wastewater sludge solids and high-strength organic wastes is well established. However, in the past decade the need to divert wastes from landfill, the requirement for the generation of renewable energy, and the requirement to reduce greenhouse gas emissions has led to the 
application of anaerobic process to a wide variety of new wastes, including food wastes, municipal solid wastes (MSW), distillery wastes, farm wastes, and slaughter house wastes $[1,5-10]$. Although $\mathrm{AD}$ is an established technology the process is often run well below its full potential and optimisation of this technology is still required, particularly in the context of digesting new feedstock types [5, 11].

The optimisation of the AD process has mainly been focused on the operational parameters such as reactor configuration, mixing, temperature, feedstock composition and pre-treatment of wastes [5, 11-21]. For example, co-digestion of different waste material, which has a number of potential benefits in AD including improving the overall availability of nutrients and the dilution of inhibitory compounds, has been effective in improving AD of new waste streams [22-28]. Co-digestion of algal sludge with waste paper and co-digestion of cattle slurry with vegetable wastes and chicken manure have both been shown to result in a doubling of methane yields $[29,30]$. However, co-digestion has also been shown to cause changes in the microbial dynamics in $\mathrm{AD}$ [31-33]. Although tools have been developed to optimise co-digestion based on AD operational performance and parameters, this has still to be done to identify and optimise the microbial communities involved in the process [34].

$\mathrm{AD}$ is a biological process therefore it is also important to understand the microbial diversity and dynamics within the digesters. It is well known that factors such as mixing, feedstock composition, and OLR/HRT can influence the structure and dynamics of the microbial community in $\mathrm{AD}$ [31-33, 35-41]. In contrast it is less well known how the structure of the microbial community influences AD performance as changes in microbial community structure can occur without detectable changes in gas production and reactor performance [42-47]. It has been suggested that high functional redundancy and microbial population variation between digesters, particularly in the 
bacterial populations, negates any clear and/or repeatable trend between performance and bacterial community structure $[43,44,48]$. However, clear relationships between the less diverse archaeal populations and the community structure have been suggested, with Methanoseta considered as an indicator of good system health while a shift to Methanosarcina could indicate periods of instability in terms of methane production $[38,49,50]$. It is possible that the lower diversity of the archaeal community, in comparison to the bacterial community, eases the understanding of the relationships between performance and community structure. However a more detailed analysis of the bacterial community can further help to understand the relationships between AD performance and bacterial community structure.

Advances in culture independent microbiology over the last 20 years, and in particular next generation sequencing (NGS) allow to examine AD microbial communities in far greater depth than previously possible [51-54]. This represents an opportunity to develop a deeper understanding of the relationships between $\mathrm{AD}$ performance and microbial community structure and function. This review seeks to highlight the value and potential of applying knowledge on the microbial communities involved in $\mathrm{AD}$ to achieve process optimisation.

\section{Overview of the microbial ecology in AD processes}

The anaerobic digestion process includes three main conversion steps carried out by the Bacteria, hydrolysis, acidogenesis, and acetogenesis, and one conversion step, methanogenesis, carried out by the archaea $[55,56]$. Disturbances at one stage have downstream effects on the other populations that often cause an imbalance in the process. This can result in the accumulation of intermediate products, indicating that the microbial community is under stress. An imbalance of the conversion products between the acid forming stages and the methanogen stage can cause an increase of volatile fatty 
acids (VFA) and a drop in $\mathrm{pH}$ [57]. Most of the methane-forming archaea are active at $\mathrm{pH}$ values between 6.8 and $7.2[50,58]$. If $\mathrm{pH}$ values in the reactor drop below this range, the archaea will be outcompeted by the fermentative bacteria which will continue to produce volatile fatty acids further lowering the $\mathrm{pH}$. In this condition, acetic acid is metabolised through other pathways such as hydrogen production or sulphate reduction and therefore low methane production is reported in digesters [59-65]. A theoretical representation of how a microbial community within $\mathrm{AD}$ may respond to perturbation is shown in Figure 1. A community can either demonstrate resistance (remain the same), resilience (change and return to original state) or adaptation and resulting in either unchanged or improved functionality in performance parameters such as methane production. The factors that influence these outcomes are at present unclear but likely to be related to the magnitude and duration as well as the type of the perturbation applied ( $\mathrm{pH}$ change, chemical inhibition or temperature for example). The outcomes will also be influenced by the initial microbial community. The key features of the microbial community that will play a significant role are yet to be investigated but could include the existence of syntrophic relationships, the functional characteristics of the individual species, overall species diversity in the community and the distribution of diversity across the community (evenness). By gaining a better understanding of the factors that control the outcomes indicated in Figure 1, environmental microbiologists, engineers and operators will be able to better predict AD performance and therefore to optimise and control the process. A consolidation of the current knowledge of the diversity present in $\mathrm{AD}$, its roles, and how the physico-chemical parameters affect them is therefore required to develop microbial optimisation of $\mathrm{AD}$. 


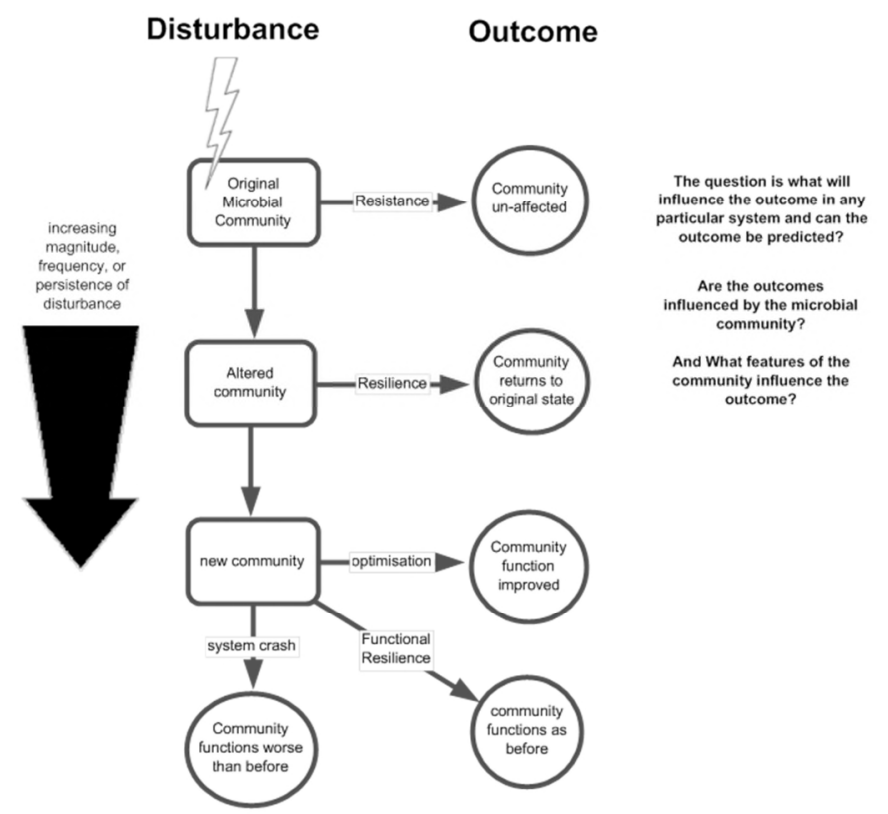

Figure 1. Theoretical response of a community to disturbance adapted from Allison and Martiny [174].

\section{Microbial diversity of anaerobic digestion}

\section{Retrieval of sequences from NCBI}

To summarise the diversity present in $\mathrm{AD}$ a set of sequences was retrieved from the National Center for Biotechnology Information (NCBI) (http://www.ncbi.nlm.nih.gov) using the search term "anaerobic digester". Sequences under 200 base pairs and those not originating from studies of AD were removed. A total of 3457 bacterial and 2946 archaeal sequences were retrieved. These sequences were aligned and clustered with the Ribosomal Data Project (RDP) pyrosequencing pipeline (http://pyro.cme.msu.edu/) and then classified using the RDP Naive Bayesian rRNA Classifier, (Version 2.5 01/05/12, Taxonomical Hierarchy: RDP 16S rRNA training set 9, Submission Date: 03 Oct 2012) using the default confidence threshold of $80 \%$ to ensure good phylogenetic resolution of all OTUs [66]. Rarefaction analysis (Figure 2) shows that at $5 \%$ phylogenetic 
distance most of the diversity had been sampled whereas at $10 \%$ phylogenetic distance

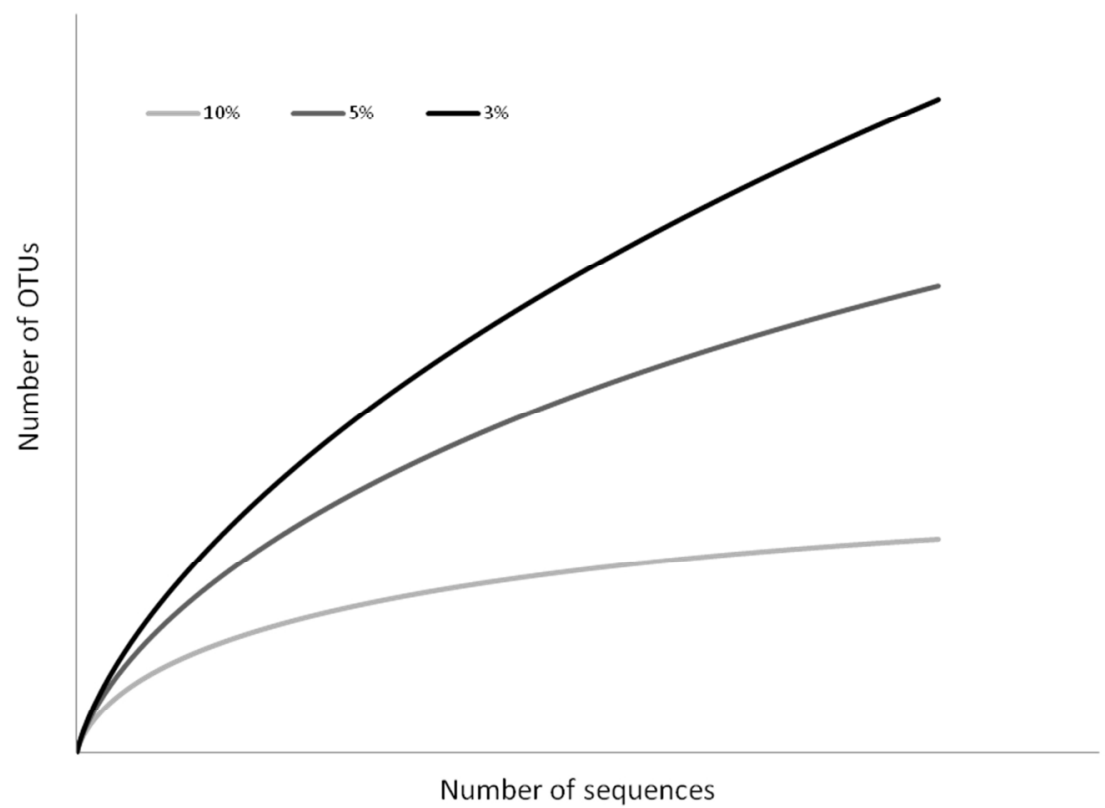

saturation had been reached.

Figure 2. Rarefraction curve of OTUs identified using Ribosomal Data Project (RDP) pyrosequencing pipeline per-sequences sampled at 3,5 , and $10 \%$ phylogenetic distance.

\subsubsection{Bacterial diversity in $A D$}

The bacterial phylum Firmicutes, accounted for 1393 sequences. Of these 841 were attributed to the class Clostridia and 233 to Bacilli. Other phyla included Proteobacteria (524 sequences) Bacteroidetes (266 sequences) Chloroflexi (81 sequences) and Actinobacteria (51 sequences) (Figure 3). Twenty-five sequences were identified for both Spirochaetes and Synergistets. Other phyla identified included Thermotogae, Tenericutes, Lentisphaerae, Armatimonadetes, Acidobacteria, Chlorobi, Deinococcus-Thermus, Planctomycetes, Fusobacteria, Caldiserica, Nitrospira, Verrucomicrobia and Fibrobacteres which all had less than 10 sequences. The ability to classify and list the diversity of the microbial communities in AD has increased with the 
advent of NGS technologies. However without an understanding of the roles of these groups and how they respond to changes in the physicochemical parameters it remains

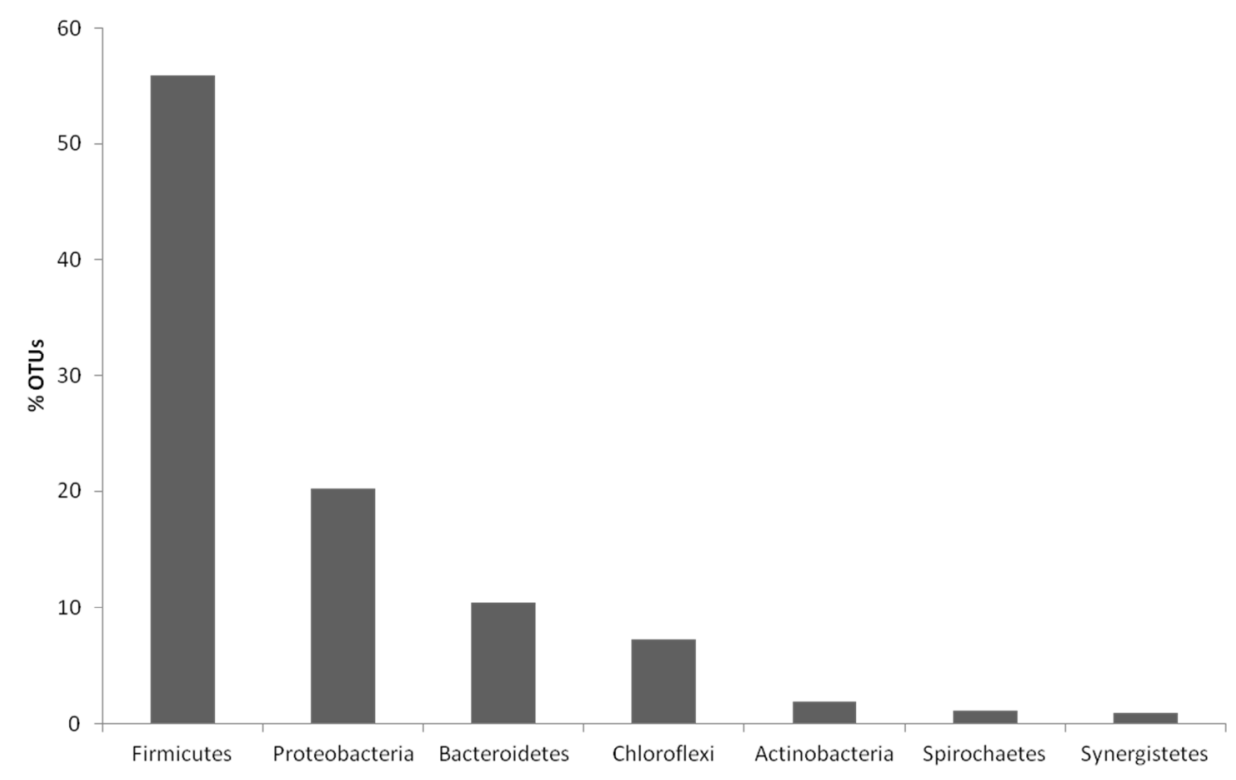

difficult to optimise $\mathrm{AD}$ processes.

Figure 3. Distribution of bacterial sequences from anaerobic digesters at Phylum level.

\section{The archaeal diversity in $A D$}

Methanogenesis is the final stage of $\mathrm{AD}$ and is carried out exclusively by methanogenic archaea belonging to the phylum Euryarchaeota. There are five orders of Euryarchaeota that can carry out methanogenesis comprising Methanopyrales, Methanococcales, Methanobacteriales, Methanomicrobiales and Methanosarcinales. All of them are obligate methane producers that derive most or all of their energy from methanogenesis $[58,67]$. An analysis of the archaeal diversity present in anaerobic digesters based on sequences retrieved from the NCBI Figure 4 showed that only the orders Methanosarcinales (1514 sequences) Methanomicrobiales (504 sequences) and Methanobacteriales (246 sequences) are predominant in AD systems. The methanogens feature a limited metabolic diversity with only three main pathways of methane 
production including the hydrogenotrophic, acetoclastic, and methylotrophic pathways. The hydrogenotrophic pathway is common to almost all methanogens while the acetoclastic and the methylotrophic pathways are restricted to the Methanosarcinales $[68,69]$. Archaea are less diverse, metabolically slower and less resilient to stress than the bacterial component of the community in AD. Methanogenesis is therefore often considered more susceptible to stress and instability than the other stages [57, 69-72]. In the following section the effect of parameters such as feedstock and VFA concentration on both the bacterial and archaeal communities are examined.

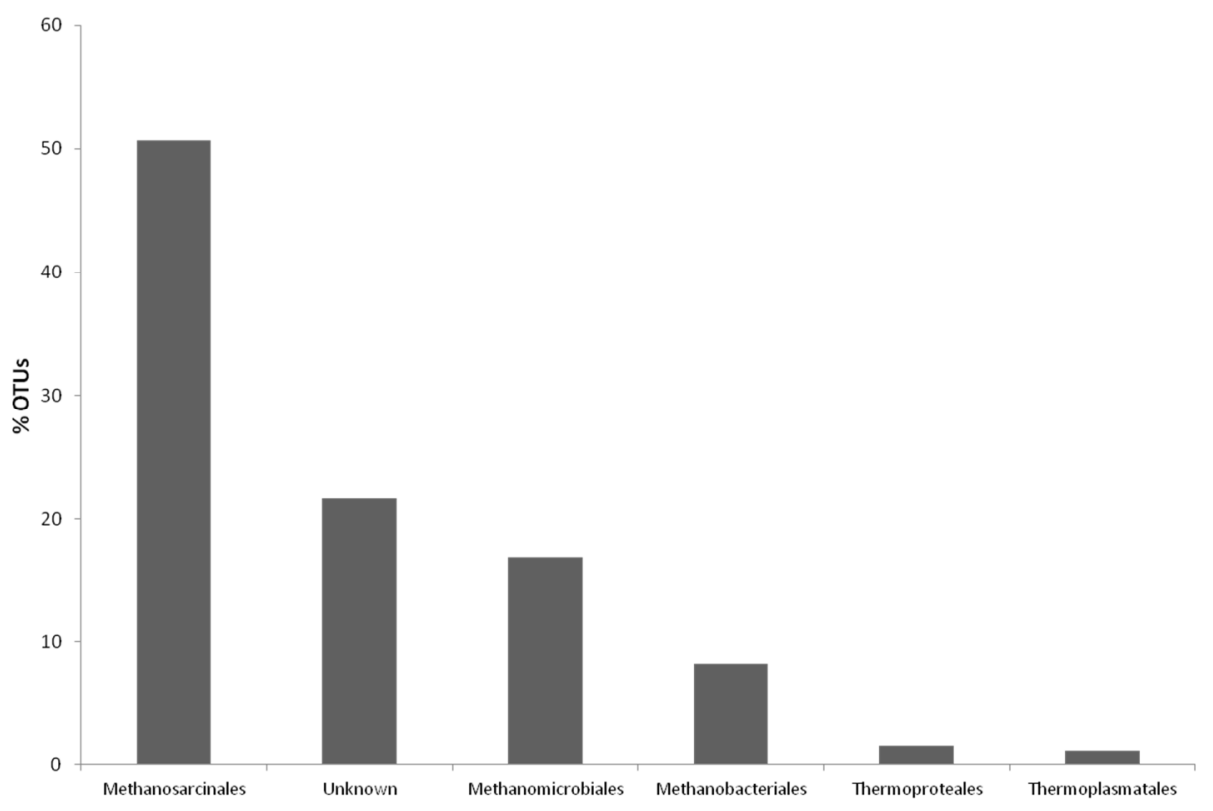

Figure 4. Distribution of methanogenic sequences from anaerobic digesters at Order level. 682 sequences were unclassified.

Influence of physicochemical parameters on microbial communities in AD

\section{Effect of feedstock on microbial community}

Bacteria are responsible for the first three stages of $\mathrm{AD}$ (hydrolysis, acidogenesis and acetogenesis) and as a result of this, they directly interact with the feedstock 
composition. This is in contrast with the archaea which are only able to convert the products of the final bacterial stages into methane. Therefore it would be expected that the structure of the bacterial community, and in particular the hydrolytic bacteria, would be heavily influenced by the feedstock characteristics. Indeed, several studies have shown that feedstock affects the bacterial community structure [31, 33, 73-75]. Most of the observed changes are within the hydrolytic groups (Clostridiales and Bacteroidetes Orders). However, the previous generation of culture independent microbiological techniques were biased towards the dominant community members. As mentioned in section 1.3.2 Clostridia and Bacteroidetes were the most common sequences in $\mathrm{AD}$ studies, it is therefore possible that the results were biased to these bacterial groups and that studies with a higher level of phylogenetic resolution will reveal less dominant but feedstock specific degrading-members. Table 1 summarises the dominant bacterial taxa retrieved in NCBI and their possible roles in AD. Clostridia are dominant in digesters with high cellulose content $[53,73,76]$ whereas Bacteroidetes are prevalent in digesters fed with protein rich feedstock such as bovine serum albumin [77] distillers grains [78] and casein [79]. The Deltaproteobacteria and Actinobacteria are associated with the digestion of lipid rich wastes and are involved in the beta-oxidation of long chain fatty acids (LCFA) [80-82].

The relationship between microbial community and the feedstock is an important factor in $\mathrm{AD}$ optimisation, particularly as $\mathrm{AD}$ expands to new feedstocks and co-digestion substrates. Changes in feedstock and co-digestion substrate can influence the microbial communities of the digesters and have subsequent consequences on the methane yields and the digesters stability. Such issues need to be understood to ensure optimal AD performance. The core populations needed for the optimal digestion of 
different feedstocks need to be identified so that AD operators can ensure optimal conditions for AD process.

Table 1. Summary of the bacterial Phyla and Classes associated with feedstock type in anaerobic digestion.

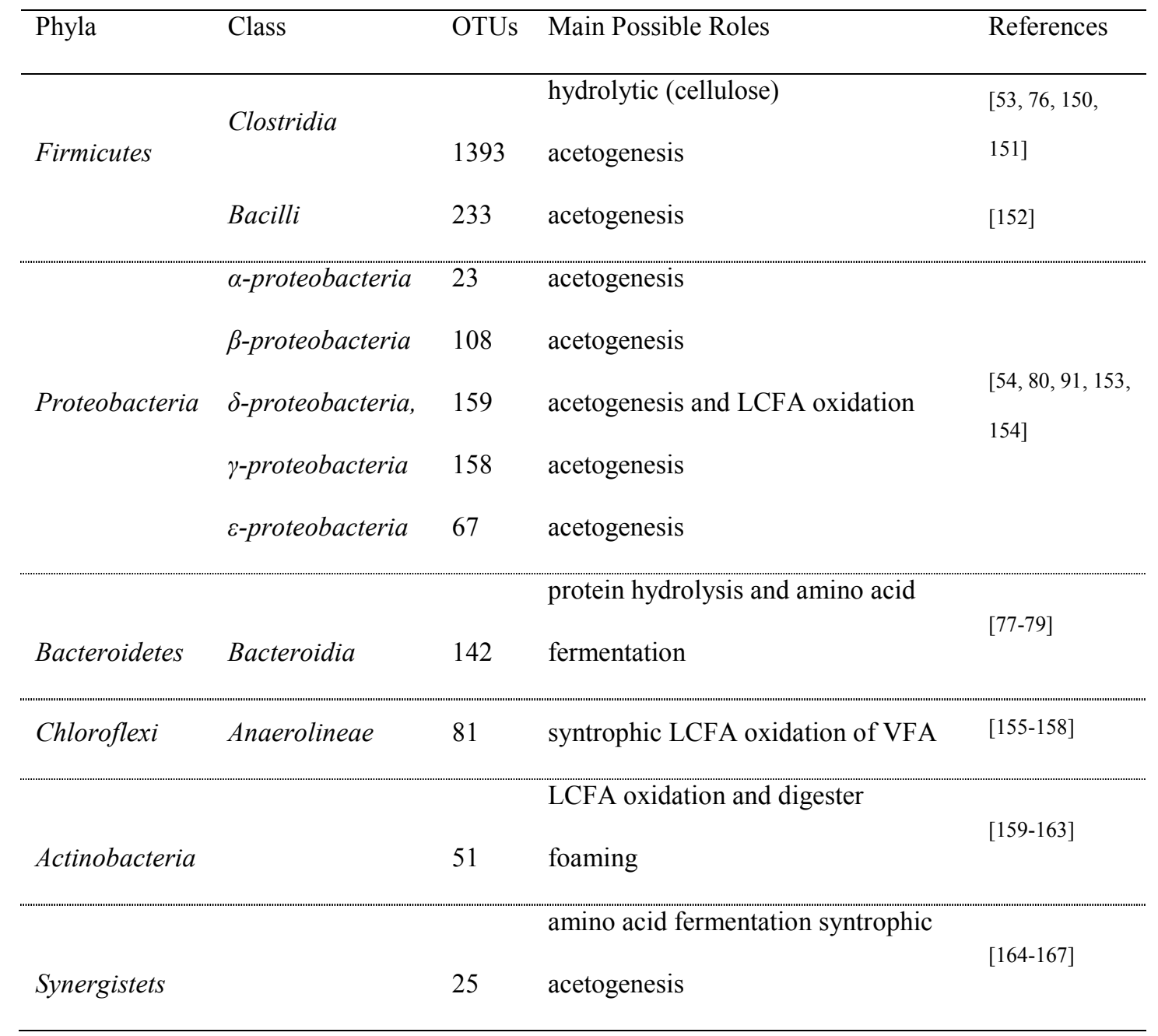

\section{Effects of organic loading rate (OLR) on the microbial community in $A D$}

OLR is a key parameter for AD operators as higher OLR corresponds to a greater amount of wastes processed. The OLR clearly affects the bacterial community present in $\mathrm{AD}$ as increase in OLR has been shown to change the amount and composition of VFA produced by the acidogenic bacteria and therefore influencing the metabolic function of the bacterial community [83]. Rincón et al. [38] showed that increasing the OLR from 0.7 to $9.1 \mathrm{~kg} \mathrm{VS} \mathrm{m}^{-3}$ day $^{-1}$ resulted in a greater bacterial diversity with a shift 
from a Clostridium dominated community to a community comprising members of Gammaproteobacteria, Actinobacteria, Bacteroidetes and Deferribacteres. Krakat et al. [84] also observed relationships between OLR and bacterial community structure with an increase of Acidobacteria and Chloroflexi ( $>65 \%$ of clones) at the highest OLR (13 $\mathrm{VS} \mathrm{m}^{-3}$ day $^{-1}$ ) and a decrease of Planctomycetes, Alcaligenaceae.

In regards to OLR effect on the methanogens, contrasting results have been reported. For example, Rincón et al. [38] reported dominance of Methanosaeta at OLR ranging from $0.7-9.1 \mathrm{~kg} \mathrm{VS} \mathrm{m}^{-3}$ day $^{-1}$ and Gomez et al. [40] also reported no change in an archaeal community comprising Methanomicrobiales, Methanosarcinales and Methanobacteriales at OLR ranging from 3.4 to $5.0 \mathrm{~kg} \mathrm{VS} \mathrm{m}^{-3} \mathrm{day}^{-1}$. In contrast, Montero et al. [85] observed an increase in Methanosaeta (acetotrophic methanogens) from $1 \%$ to $30 \%$ as OLR was increased from 4.4 to $7.2 \mathrm{~kg} \mathrm{VS} \mathrm{m}^{-3} \mathrm{day}^{-1}$ and a corresponding decrease of Methanobacteriaceae from $11 \%$ to $7 \%$ (hydrogenotrophic methanogens). Further to this, Lerm et al. [86] recently showed a reverse relationship with a switch from Methanosarcina to the exclusively hydrogenotrophic methanogens Methanospirillum and Methanoculleus as OLR was increased from 2.5 to $40 \mathrm{~kg} \mathrm{VS} \mathrm{m}^{-3}$ day $^{-1}$. The archaeal shift observed by Lerm et al.[86] can be related to a significant increase in the VFA concentration and/or an organic overload of the digesters suggesting that OLR only affects the archaeal community if it results in changes in other parameters such as VFA concentration and $\mathrm{pH}$.

Overall the studies discussed here on the influence of OLR on the Bacteria and Archaea involved in AD highlighted contrasting effects and therefore the difficulty of developing a predictive understanding of the relationship between digester performance and microbial community structure and dynamics. 


\section{Effects of VFA composition and concentration on microbial community}

VFA are intermediate products produced during acidogenesis and acetogenesis. Acetic acid is the key substrate for methanogenesis, but if its production rate is faster than its utilisation rate by the methanogens, digester instability will occur. For example, shift in the archaeal population from Methanosaeta to Methanosarcina in digesters experiencing a VFA increase from to more than $1.5 \mathrm{~g}^{-1}$ has been observed by several authors [87-90]. Hori et al [57] also showed that VFA accumulation resulted in a 10,000 fold increase in the gene expression for the hydrogenotrophic methanogen Methanothermobacter and Delbès et al. [70] reported the dominance of Methanobacterium at high acetic acid concentrations ( $>3 \mathrm{~g} / \mathrm{l})$. Analysis with fluorescence in situ hybridization (FISH) indicated that syntrophic interactions between hydrogenotrophic methanogens and bacteria is key in the degradation of VFA and recovery of digesters [57]. McMahon et al. [91] further showed that digesters with a history of poor performance had proportionally higher numbers of Methanosarcina than Methanosaeta as well as a higher number of syntrophic bacteria including Syntrophobacter, Smithella, and Syntrophomonadaceae, and consequently that the microbial community of the digesters was more tolerant to VFA accumulation as a result of the high organic loading. These results demonstrate that the structure of the microbial community can positively influence AD performance. Clearly higher numbers of syntrophic Archaea and bacteria are desirable for AD which can be increased by past stress in the reactor. This can be related to Figure 1 as a perturbation altering the community structure and resulting in optimised performance.

Although the relationship between the VFA concentration and the archaeal community dynamics are well understood, our understanding of the relationship between the bacterial community dynamics and the VFA composition and concentration 
is still limited. A relationship between acetic acid concentration and Clostridia abundance was proposed by Delbès et al [70]. However in a previous study, Delbès et al. [92] reported no difference in the bacterial response to acetate, propionate, or butyrate suggesting that quantifying the total concentration of VFA was more important than reporting the concentration of speciated VFA. This finding is somewhat surprising as bacteria are the VFA producers in AD and therefore likely to influence the VFA composition and concentration in $\mathrm{AD}$ systems. Also it has been demonstrated that propionic acid has a higher inhibition effect than acetic and butyric acids on methane production $[64,93]$. This controversial finding reinforces the need to further investigate the relationship between specific archaeal/bacterial groups and specific VFA.

\section{Effect of ammonia on the microbial community}

Many farm wastes including pig slurries, slaughter wastes, cattle and poultry manure have high concentration of ammonia which can be either inhibitory or beneficial to maintain optimal AD process [94-99]. Several studies have reported significant increase of hydrogenotrophic methanogens belonging to Methanosarcinaceae, and to a less extent to Methanomicrobiales and Methanobacteriales in digesters with ammonia concentration of $>3 \mathrm{~g} \mathrm{l}^{-1}[87,100,101]$. The formation of multicellular units by Methanosarcinaceae at high concentrations of ammonia protects them and also results in more efficient syntrophic relationships between methanogens and bacteria for interspecies hydrogen transfer. The hydrogenotrophic methanogens are therefore favoured under this condition instead of the acetotrophic methanogens $[100,102]$. This can be related to Figure 1 as an example of a perturbation (increase in ammonia concentration) causing a shift in the microbial community structure and function (switch to hydrogenotrophic methanogenesis) which can preserve AD function. 
In contrast, the effect of ammonia on the bacteria is unclear and results suggest that the methanogens are inhibited well before ammonia affects the bacteria [103]. Koster and Lettinga [104] showed that the production of VFA by bacteria is not significantly affected by ammonia concentration. They also demonstrated that after exposing digesters to ammonia concentration up to $9 \mathrm{~g}^{-1}$ for three weeks, ammonia tolerance by the methanogens was improved by 6 times. This finding suggests that the microbial community of digesters can be easily optimised to produce methane from feedstocks with high ammonia. This can be related to Figure 1 as a disturbance (high ammonia) resulting in an optimised community. To date, while the mechanism of this adaption is not fully understood, the predominance of the hydrogenotrophic methanogens and the favoured syntrophic interactions with the bacteria at high ammonia concentration suggest that the acclimation of the community to high VFA concentrations is related to changes in the community structure.

\section{Effect of trace metals on AD microbial communities}

The availability of trace metals in $\mathrm{AD}$ and effect on performance has been a major topic of research for over 30 years [15, 105-109]. Additions of trace metals such as cobalt, molybdenum, iron, nickel selenium, and sulphate have been shown to improve methane yields [107, 110-114], improve stability [115-119], and optimise long-term AD performance $[120,121]$ largely through reducing accumulation of VFA. It is known that trace metals such as cobalt, nickel, iron, zinc, molybdenum, and tungsten are important for the activity of the enzymes involved in methane production in $\mathrm{AD}[122,123]$.

Despite this the effect of trace metal concentration and addition on the structure of the microbial community structure has not been extensively researched. Fermoso et al. [124] observed decrease in numbers of Methanosarcina and associated decrease in performance parameters under cobalt limited conditions in a UASB reactor treating 
methanol, results also suggested cobalt addition may be a suitable strategy for recovering Methanosarcina populations. Banks et al. [121] showed that the dominant methanogenic populations in digesters with high ammonia concentration (4-6 g 1 ${ }^{-1}$ TAN) and varying trace metals concentrations were Methanoimicrobiales indicating that ammonia concentration was a more important factor than trace metals in structuring the methanogenic community. Feng et al [48] investigated the effect of additions of cobalt alone, a combination of nickel/molybdenum/boron, or a combination of selenium/tungsten on microbial community structure and AD performance. The best methane production was related to high selenium and tungsten concentration with low cobalt. Trace metals concentration did not influence the relative abundance of the most dominant bacterial population (Actinobacteria) but two bacterial populations both related to Firmicutes were positively correlated with the nickel/molybdenum/boron treatment alone and negatively correlated with nickel/molybdenum/boron combined with cobalt. The archaeal populations showed a much greater correlation with the trace metals with a Methanoculleus population positively correlated with selenium and tungsten alone but negatively correlated with nickel/molybdenum/boron and selenium and tungsten when they were supplemented together. In contrast Methanosarcina population was positively correlated with the nickel/molybdenum/boron treatment. Feng et al. [48] demonstrated that trace metals influence the structure of the bacterial and archaeal populations in $\mathrm{AD}$, however the response of archaeal populations from the same genus differed, and when nickel/molybdenum/boron was used in combination with cobalt the correlation was reversed. This shows that the relationship between microbial populations in $\mathrm{AD}$ and trace metals is complicated and that different combinations of trace metal supplementations can have antagonistic effects. As it is clear that trace metal concentration is a key parameter in optimizing $\mathrm{AD}$ more research 
is required to understand the influence of trace metals on the microbial community to fully exploit this knowledge to optimise AD.

\section{Microbial optimisation of AD}

\section{Bioaugmentation for AD optimisation}

Bioaugmentation with a particular species or consortium of species could allow plant operations to change the existing microbial community so that it is optimised to carry out a specific function $[125,126]$. Bioaugmentation has been used for the remediation of contaminated soils and ground waters and has also been applied extensively to aerobic wastewater treatment [125-133]. Bioaugmentation has been also applied towards the optimisation of a number of aspects of anaerobic digestion including degradation of problematic feedstocks with high cellulose or lipid content, improvement of recovery from perturbation, and faster start-up times (Table 2). However bioaugmentation is not always successful and further research is required to develop bioaugmentation as an optimisation strategy in $\mathrm{AD}$ [134]. The effect of bioaugmentation on the indigenous community needs to be examined as interactions such as predation and competition may result in negative effects on the community rather than improved performance. Additionally the survival and integration of the exogenous population into the reactor needs to be examined to establish how to maintain the effect of bioaugmentation over long periods. Perhaps the most important question to address is what species/cultures are going to have a beneficial effect on the community. To answer this question, further research identifying novel species with beneficial physiological traits, as reported by $[135,136]$ will be useful. Another important approach will be the analysis of microbial communities in digesters under specific conditions, such as recovering from overload, so that an understanding of what 
type of community consortium will be desirable for a certain situation can be developed.

Table 2. Summary of successful bioaugmentation studies in AD.

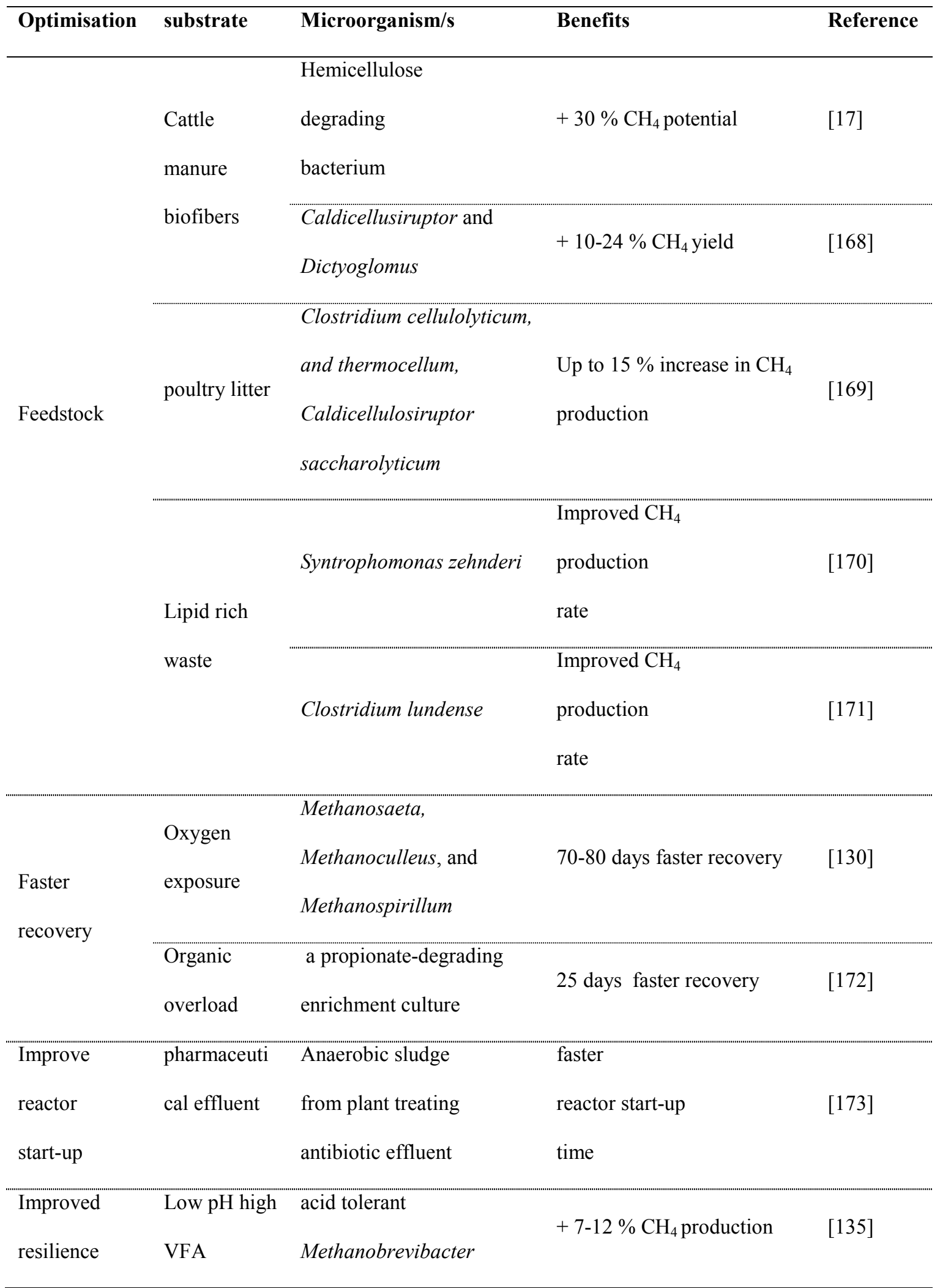




\section{Manipulation of process and AD design for microbial optimisation}

An alternative to bioaugmentation is to promote microbial community diversity by changing the operational conditions of AD. Research has shown that digesters with greater flexibility in microbial community structure are more resilient to perturbation than more stable communities [42, 137]. Hashsham et al. [137] showed that digesters that were able to process feed through a network of multiple routes in parallel were more stable than those that processed feed through sequential pathways. Therefore promoting functional diversity in the microbial community is one possibility for improving AD stability. This has been recognised and incorporated into the design of AD systems such as baffled digesters or membrane reactors. Functional diversity can also be promoted by using granular substrates [138]. It was suggested by Briones $\&$ Raskin [138] that incorporating changes in operational conditions such as modifying the OLR can also enhance the functional diversity and performance of the digesters. This was also proposed by McMahon et al. (2004). More recently Palatsi et al. [139] showed that digesters exposed to repeated LCFA pulses had faster recovery times. Therefore there is mounting evidence that the resilience of $\mathrm{AD}$ microbial communities can be enhanced through manipulation of the operational conditions which can be subsequently used to optimise $\mathrm{AD}$ process.

\section{Microbial community monitoring as decision support tool for AD performance}

The lack of reliable sensory equipment and control systems have been reported as one of the major reasons for $\mathrm{AD}$ not being operated at optimal conditions [11]. This was stated in the context of monitoring the biochemical process, however as demonstrated in this review the microbial community must be considered in AD optimisation. Talbot et 
al [51] in a review of nucleic acid based techniques to characterise communities in AD systems point to the development of laboratory-on-chip systems for eventual on-line monitoring of bioreactors. This technology has already been demonstrated for fast characterization the human gut microbiota, where similar microbial consortium are found [140]. Microarray chips have also been successful in characterising the archaeal community in anaerobic sludge, and therefore it is appropriate to think that an accurate, viable and cheap method for monitoring microbial communities in $\mathrm{AD}$ will be available soon [141].

The development of culture independent techniques such as phospholipids analysis (PLFA), denaturing gradient gel electrophoresis (DGGE), single strand conformation polymorphism (SSCP) and others for microbial community fingerprinting has undoubtedly improved our understanding of microbial communities in $\mathrm{AD}[44,92$, $100,102,142]$. Fingerprinting techniques, such as DGGE have proved more effective in studying the less diverse archaeal community than the highly diverse bacterial community. This is due to the relative complexity of the bacterial community which is therefore much more challenging to characterise. Community fingerprinting has allowed microbiologists to look at community shifts in relation to changes in the physicochemical parameters, such as VFA profiles, in AD. The application of the socalled next generation sequencing technologies, such as 454-pyrosequencing, represents one of the most exciting areas of development in $\mathrm{AD}$. Combining 454-pyrosequencing to phylogenetic microarray has provided a cost effective way of obtaining highresolution data on microbial community structures and function in AD. Schlüter et al. [53] and Kröber et al. [52] analysed the microbial communities in a production scale AD plant fed with maize silage, green rye and liquid manure. The data obtained in these studies far surpasses the depth of information gained in previous studies based on 
fingerprinting techniques. For example the identification of less dominant members such as Syntrophobacterales and Synergistia have been shown to have greater correlation with the changes in performance observed [54]. As NGS technologies become cheaper and the strategies for analysing the data get more refined, our understanding of the structure and function of microbial communities, such as those found in $\mathrm{AD}$ reactors will improve exponentially. However, these techniques still provide limited quantitative information. To this end, analysis of the lipid content of the community including phospholipid-derived fatty acids (PLFA) for bacteria and

phospholipids etherlipid (PLEL) for archaea can reveal changes in biomass and function of microbial communities [142-147]. In particular, Schwarzenauer and Illmer [147] showed that monitoring PLFA could identify changes in the microbial community associated with changes in AD performance. The relative cheapness of lipid fingerprinting and the use of high throughput PLFA techniques, developed by Buyer and Sasser [148], make it possible to monitor changes in biomass and lipid structure over long time series, at both lab and potentially full scale operational AD plants. Lipid fingerprinting, which are overlooked by many microbiologists outside soil science, can represent a valuable tool in AD optimisation.

\section{Conclusions and research gaps}

The preceding sections of this review have summarised some of the recent developments in microbial ecology in AD. Culture independent analysis of communities has improved our understanding of the process but even so there is no obvious direct application of this information to deliver significant process optimisation in AD. Industry remains sceptical to the benefit that microbial optimisation can provide and this will remain the case until the benefits of microbial optimisation can be empirically proved. There is a perception that the microbial communities are so diverse that it will 
not be possible to produce a clear understanding of the role of the microbial community.

This perception is supported by research showing highly dynamic communities in stable reactors which gives weight to the argument that community shifts are not related to performance [43]. As reported in this review there is a great deal of work demonstrating that the methanogenic community is influenced by the concentrations of intermediate products such as VFA and other inhibitory compounds such as ammonia. The factors that influence the bacterial community are less understood, but the improved resolution of NGS in combination with other techniques such as lipid fingerprinting may help to improve our understanding of this aspect of the AD community. McMahon et al. [149] called for the integration of microbial ecology and engineering so that novel approaches to manipulating systems can be developed. For example it has been hypothesised that it may be possible to develop more resilient communities by changing operational conditions, rather than letting a community become specialised [138, 149]. Potential effects that a perturbation may have on a microbial community in $\mathrm{AD}$ are illustrated in Figure 1. Filling the gaps of knowledge highlighted on this figure will enable optimisation of the $\mathrm{AD}$ process and also contribute to the field of microbial ecology in general.

\section{Acknowledgements}

The authors are grateful to EPSRC and QUESTOR for funding.

\section{References:}

1. Weiland P., Biogas production: current state and perspectives. Applied Microbiology and Biotechnology, 85, 849-860 (2011).

2. Chan Y.J., Chong M.F., Law C.L. and Hassell D.G., A review on anaerobicaerobic treatment of industrial and municipal wastewater. Chemical Engineering Journal, 155, 1-18 (2009). 
3. Parkin G. and Owen W., Fundamentals of Anaerobic Digestion of Wastewater Sludges. Journal of Environmental Engineering, 112, 867-920 (1986).

4. $\quad$ Sekiguchi Y., Kamagata Y. and Harada H., Recent advances in methane fermentation technology. Current opinion in biotechnology, 12, 277-282 (2001).

5. Mata-Alvarez J., Macé S. and Llabrés P., Anaerobic digestion of organic solid wastes. An overview of research achievements and perspectives. Bioresource technology, 74, 3-16 (2000).

6. Bouallagui H., Touhami Y., Ben Cheikh R. and Hamdi M., Bioreactor performance in anaerobic digestion of fruit and vegetable wastes. Process Biochemistry, 40, 989-995 (2005).

7. Bishop C. and Shumway C., The Economics of Dairy Anaerobic Digestion with Coproduct Marketing. Applied Economic Perspectives and Policy, 31, 394-410 (2009).

8. Kryvoruchko V., Machmüller A., Bodiroza V., Amon B. and Amon T., Anaerobic digestion of by-products of sugar beet and starch potato processing. Biomass and Bioenergy, 33, 620-627 (2009).

9. Clemens J., Trimborn M., Weiland P. and Amon B., Mitigation of greenhouse gas emissions by anaerobic digestion of cattle slurry. Agriculture, Ecosystems \& Environment, 112, 171-177 (2006).

10. Iacovidou E., Ohandja D.G. and Voulvoulis N., Food waste co-digestion with sewage sludge--realising its potential in the UK. Journal of Environmental Management, 112, 267-274 (2012).

11. Ward A.J., Hobbs P.J., Holliman P.J. and Jones D.L., Optimisation of the anaerobic digestion of agricultural resources. Bioresource technology, 99, 7928-7940 (2008).

12. Ince O., Performance of a two-phase anaerobic digestion system when treating dairy wastewater. Water Research, 32, 2707-2713 (1998).

13. Demirer G.N. and Chen S., Two-phase anaerobic digestion of unscreened dairy manure. Process Biochemistry, 40, 3542-3549 (2005).

14. Stroot P.G., McMahon K.D., Mackie R.I. and Raskin L., Anaerobic codigestion of municipal solid waste and biosolids under various mixing conditions 1. Digester performance. Water research, 35, 1804-1816 (2001).

15. Appels L., Baeyens J., Degrève J. and Dewil R., Principles and potential of the anaerobic digestion of waste-activated sludge. Progress in Energy and Combustion Science, 34, 755-781 (2008).

16. Bouallagui H., Marouani L. and Hamdi M., Performances comparison between laboratory and full-scale anaerobic digesters treating a mixture of primary and waste activated sludge. Resources, Conservation and Recycling, 55, 29-33 (2010). 
17. Angelidaki I., Ahring B.K. and Ahring B.K., Methods for increasing the biogas potential from the recalcitrant organic matter contained in manure. Water Science and Technology 41, 189-194 (2000).

18. Khanal S.K., Grewell D., Sung S. and van Leeuwen J., Ultrasound Applications in Wastewater Sludge Pretreatment: A Review. Critical Reviews in Environmental Science and Technology, 37, 277 - 313 (2007).

19. Wang W., Hou H., Hu S. and Gao X., Performance and stability improvements in anaerobic digestion of thermally hydrolyzed municipal biowaste by a biofilm system. Bioresource Technology, 101, 1715-1721 (2010).

20. Apul O.G. and Sanin F.D., Ultrasonic pretreatment and subsequent anaerobic digestion under different operational conditions. Bioresource Technology, 101, 89848992 (2010).

21. Stafford D.A., The effects of mixing and volatile fatty acid concentrations on anaerobic digester performance. Biomass, 2, 43-55 (1982).

22. Zhang Y. and Banks C.J., Co-digestion of the mechanically recovered organic fraction of municipal solid waste with slaughterhouse wastes. Biochemical Engineering Journal, 68, 129-137 (2012).

23. Zhang Y., Banks C.J. and Heaven S., Co-digestion of source segregated domestic food waste to improve process stability. Bioresource Technology, 114, 168178 (2012).

24. Zhang Y., Zamudio Canas E.M., Zhu Z., Linville J.L., Chen S. and He Q., Robustness of archaeal populations in anaerobic co-digestion of dairy and poultry wastes. Bioresource Technology (2010).

25. Siles J.A., Martin M.A., Chica A.F. and Martin A., Anaerobic co-digestion of glycerol and wastewater derived from biodiesel manufacturing. Bioresource technology, 101, 6315-6321 (2010).

26. Chen G., Zheng Z., Yang S., Fang C., Zou X. and Zhang J., Improving conversion of Spartina alterniflora into biogas by co-digestion with cow feces. Fuel Processing Technology, 91, 1416-1421 (2010).

27. Chen G., Zheng Z., Yang S., Fang C., Zou X. and Luo Y., Experimental codigestion of corn stalk and vermicompost to improve biogas production. Waste Management, 30, 1834-1840 (2010).

28. Callaghan F.J., Luecke K., Wase D.A., Thayanithy K. and Forster C.F., CoDigestion of Cattle Slurry and Waste Milk under Shock Loading Conditions. Journal of Chemical Technology and Boitechnology, 68, 405-410 (1999).

29. Callaghan F.J., Wase D.A.J., Thayanithy K. and Forster C.F., Continuous codigestion of cattle slurry with fruit and vegetable wastes and chicken manure. Biomass and Bioenergy, 22, 71-77 (2002). 
30. Yen H.-W. and Brune D.E., Anaerobic co-digestion of algal sludge and waste paper to produce methane. Bioresource Technology, 98, 130-134 (2007).

31. Wang H., Lehtomäki A., Tolvanen K., Puhakka J. and Rintala J., Impact of crop species on bacterial community structure during anaerobic co-digestion of crops and cow manure. Bioresource Technology, 100, 2311-2315 (2009).

32. Martin-Gonzalez L., Castro R., Pereira M.A., Alves M.M., Font X. and Vicent T., Thermophilic co-digestion of organic fraction of municipal solid wastes with FOG wastes from a sewage treatment plant: Reactor performance and microbial community monitoring. Bioresource Technology, 102, 4734-4741 (2011).

33. Supaphol S., Jenkins S.N., Intomo P., Waite I.S. and Donnell A.G., Microbial community dynamics in mesophilic anaerobic co-digestion of mixed waste. Bioresource Technology, 102, 4021-4027 (2011).

34. Ãlvarez J.A., Otero L. and Lema J.M., A methodology for optimising feed composition for anaerobic co-digestion of agro-industrial wastes. Bioresource Technology, 101, 1153-1158 (2010).

35. McMahon K.D., Stroot P.G., Mackie R.I. and Raskin L., Anaerobic codigestion of municipal solid waste and biosolids under various mixing conditions II: microbial population dynamics. Water research, 35, 1817-1827 (2001).

36. Kaparaju P., Buendia I., Ellegaard L. and Angelidakia I., Effects of mixing on methane production during thermophilic anaerobic digestion of manure: Lab-scale and pilot-scale studies. Bioresource Technology, 99, 4919-4928 (2008).

37. Akarsubasi A.T., Ince O., Kirdar B., Oz N.A., Orhon D., Curtis T.P., Head I.M. and Ince B.K., Effect of wastewater composition on archaeal population diversity. Water research, 39, 1576-1584 (2005).

38. Rincón B., Borja R., González J.M., Portillo M.C. and Sáiz-Jiménez C., Influence of organic loading rate and hydraulic retention time on the performance, stability and microbial communities of one-stage anaerobic digestion of two-phase olive mill solid residue. Biochemical engineering journal, 40, 253-261 (2008).

39. Chen S., Zamudio Cañas E.M., Zhang Y., Zhu Z. and He Q., Impact of substrate overloading on archaeal populations in anaerobic digestion of animal waste. Journal of Applied Microbiology, 113, 1371-1379 (2012).

40. Gomez E., Martin J. and Michel F.C., Effects of organic loading rate on reactor performance and archaeal community structure in mesophilic anaerobic digesters treating municipal sewage sludge. Waste Management \& Research, 29, 1117-1123 (2011).

41. Bialek K., Kumar A., Mahony T., Lens P.N.L. and O' Flaherty V., Microbial community structure and dynamics in anaerobic fluidized-bed and granular sludge-bed reactors: influence of operational temperature and reactor configuration. Microbial Biotechnology, 5, 738-752 (2012). 
42. Fernández A.S., Hashsham S.A., Dollhopf S.L., Raskin L., Glagoleva O., Dazzo F.B., Hickey R.F., Criddle C.S. and Tiedje J.M., Flexible Community Structure Correlates with Stable Community Function in Methanogenic Bioreactor Communities Perturbed by Glucose. Applied and Environmental Microbiology, 66, 4058-4067 (2000).

43. Fernández A., Huang S., Seston S., Xing J., Hickey R., Criddle C. and Tiedje J., How stable is stable? Function versus community composition. Applied and environmental microbiology, 65, 3697-3697 (1999).

44. Kaewpipat K. and GradyJr C.P., Microbial population dynamics in laboratoryscale activated sludge reactors. water Science and Technology, 46, 19-27 (2002).

45. Zumstein E., Moletta R. and Godon J.-J., Examination of two years of community dynamics in an anaerobic bioreactor using fluorescence polymerase chain reaction (PCR) single-strand conformation polymorphism analysis. Environmental Microbiology, 2, 69-78 (2000).

46. Wang X., Wen X., Criddle C., Yan H., Zhang Y. and Ding K., Bacterial community dynamics in two full-scale wastewater treatment systems with functional stability. Journal of Applied Microbiology, 109, 1218-1226 (2010).

47. Wang X., Wen X., Yan H., Ding K., Zhao F. and Hu M., Bacterial community dynamics in a functionally stable pilot-scale wastewater treatment plant. Bioresource Technology, 102, 2352-2357 (2011).

48. $\quad$ Feng X.M., Karlsson A., Svensson B.H. and Bertilsson S., Impact of trace element addition on biogas production from food industrial waste - linking process to microbial communities. FEMS Microbiology Ecology, 74, 226-240 (2011).

49. Blume F., Bergmann I., Nettmann E., Schelle H., Rehde G., Mundt K. and Klocke M., Methanogenic population dynamics during semi-continuous biogas fermentation and acidification by overloading. Journal of Applied Microbiology, 109, 441-450 (2010).

50. Demirel B. and Scherer P., The roles of acetotrophic and hydrogenotrophic methanogens during anaerobic conversion of biomass to methane: a review. Reviews in Scientific Biotechnology, 7, 173-190 (2008).

51. Talbot G., Topp E., Palin M.F. and Massé D., Evaluation of molecular methods used for establishing the interactions and functions of microorganisms in anaerobic bioreactors. Water research, 42, 513-537 (2008).

52. Kröber M., Bekel T., Diaz N.N., Goesmann A., Jaenicke S., Krause L., Miller D., Runte K.J., Viehöver P., Pühler A. and Schlüter A., Phylogenetic characterization of a biogas plant microbial community integrating clone library 16S-rDNA sequences and metagenome sequence data obtained by 454-pyrosequencing. Journal of Biotechnology, 142, 38-49 (2009).

53. Schlüter A., Bekel T., Diaz N.N., Dondrup M., Eichenlaub R., Gartemann K.-H., Krahn I., Krause L., Krömeke H., Kruse O., Mussgnug J.H., Neuweger H., Niehaus K., Pühler A., Runte K.J., Szczepanowski R., Tauch A., Tilker A., Viehöver P. and Goesmann A., The metagenome of a biogas-producing microbial community of a 
production-scale biogas plant fermenter analysed by the 454-pyrosequencing technology. Journal of Biotechnology, 136, 77-90 (2008).

54. Werner J.J., Knights D., Garcia M.L., Scalfone N.B., Smith S., Yarasheski K., Cummings T.A., Beers A.R., Knight R. and Angenent L.T., Bacterial community structures are unique and resilient in full-scale bioenergy systems. Proceedings of the National Academy of Sciences of the United States of America, 108, 4158-4163 (2012).

55. Braber K., Anaerobic digestion of municipal solid waste: A modern waste disposal option on the verge of breakthrough. Biomass and Bioenergy, 9, 365-376 (1995).

56. O'Flaherty V., Collins G., Mahony T. and se, The Microbiology and Biochemistry of Anaerobic Bioreactors with Relevance to Domestic Sewage Treatment. Reviews in Environmental Science and Biotechnology, 5, 39-55 (2006).

57. Hori T., Haruta S., Ueno Y., Ishii M. and Igarashi Y., Dynamic transition of a methanogenic population in response to the concentration of volatile fatty acids in a thermophilic anaerobic digester. Applied and Environmental Microbiology, 72, 16231630 (2006).

58. Garcia J.-L., Patel B.K.C. and Ollivier B., Taxonomic, Phylogenetic, and Ecological Diversity of Methanogenic Archaea. Anaerobe, 6, 205-226 (2000).

59. Van Den Berg L., Lamb K.A., Murray W.D. and Armstrong D.W., Effects of Sulphate, Iorn and Hydrogen on the Microbiological Conversion of Acetic Acid to Methane. journal of applied Bacteriology, 48, 437-447 (1980).

60. Conrad R., Contribution of hydrogen to methane production and control of hydrogen concentrations in methanogenic soils and sediments. FEMS Microbiology Ecology, 28, 193-202 (1999).

61. Schnürer A., Zellner G. and Svensson B.H., Mesophilic syntrophic acetate oxidation during methane formation in biogas reactors. FEMS Microbiology Ecology, 29, 249-261 (1999).

62. Zhang B., Cai W.M. and He P.J., Influence of lactic acid on the two-phase anaerobic digestion of kitchen wastes. J Environ Sci, 19, 244-249 (2007).

63. Qu X., Mazéas L., Vavilin V.A., Epissard J., Lemunier M., Mouchel J.-M., He P.-j. and Bouchez T., Combined monitoring of changes in $\delta 13 \mathrm{CH} 4$ and archaeal community structure during mesophilic methanization of municipal solid waste. FEMS Microbiology Ecology, 68, 236-245 (2009).

64. Wang Y., Zhang Y., Wang J. and Meng L., Effects of volatile fatty acid concentrations on methane yield and methanogenic bacteria. Biomass and Bioenergy, $33,848-853$ (2009).

65. Laukenmann S., Polag D., Heuwinkel H., Greule M., Gronauer A., Lelieveld J. and Keppler F., Identification of methanogenic pathways in anaerobic digesters using stable carbon isotopes. Engineering in Life Sciences, 10, 509-514 (2011). 
66. Wang Q., Garrity G.M., Tiedje J.M. and Cole J.R., Naïve Bayesian Classifier for Rapid Assignment of rRNA Sequences into the New Bacterial Taxonomy. Applied and Environmental Microbiology, 73, 5261-5267 (2007).

67. Thauer R.K., Kaster A.-K., Seedorf H., Buckel W. and Hedderich R., Methanogenic archaea: ecologically relevant differences in energy conservation. Nature Reviews Microbiology, 6, 579-591 (2008).

68. Luo H., Sun Z., Arndt W., Shi J., Friedman R. and Tang J., Gene Order Phylogeny and the Evolution of Methanogens. PLoS ONE, 4, e6069 (2009).

69. Liu Y. and Whitman W.B., Metabolic, Phylogenetic, and Ecological Diversity of the Methanogenic Archaea. Annals of the New York Academy of Sciences, 1125, 171189 (2008).

70. Delbès C., Moletta R. and Godon J.-J., Bacterial and archaeal 16S rDNA and 16S rRNA dynamics during an acetate crisis in an anaerobic digestor ecosystem. FEMS Microbiology Ecology, 35, 19-26 (2001).

71. Leclerc M., Delbes C., Moletta R. and Godon J.-J., Single strand conformation polymorphism monitoring of $16 \mathrm{~S}$ rDNA Archaea during start-up of an anaerobic digester. FEMS Microbiology Ecology, 34, 213-220 (2001).

72. Lee C., Kim J., Shin S.G. and Hwang S., Monitoring bacterial and archaeal community shifts in a mesophilic anaerobic batch reactor treating a high-strength organic wastewater. FEMS Microbiology Ecology, 65 544-554 (2008).

73. Xia Y., Cai L., Zhang T. and Fang H.H.P., Effects of substrate loading and cosubstrates on thermophilic anaerobic conversion of microcrystalline cellulose and microbial communities revealed using high-throughput sequencing. International Journal of Hydrogen Energy, 37, 13652-13659 (2012).

74. Nelson M.C., Morrison M., Schanbacher F. and Yu Z., Shifts in microbial community structure of granular and liquid biomass in response to changes to infeed and digester design in anaerobic digesters receiving food-processing wastes.

Bioresource Technology, 107, 135-143 (2012).

75. Shen P., Zhang J., Zhang J., Jiang C., Tang X., Li J., Zhang M. and Wu B., Changes in microbial community structure in two anaerobic systems to treat bagasse spraying wastewater with and without addition of molasses alcohol wastewater.

Bioresource Technology (2012).

76. Syutsubo K., Nagaya Y., Sakai S. and Miya A., Behavior of cellulose-degrading bacteria in thermophilic anaerobic digestion process. Water Science and Technology, 52, 79-84 (2005).

77. Tang Y., Shigematsu T., Morimura S. and Kida K., Microbial community analysis of mesophilic anaerobic protein degradation process using bovine serum albumin (BSA)-fed continuous cultivation. Journal of Bioscience and Bioengineering, 99, 150-164 (2005). 
78. Ziganshin A., Schmidt T., Scholwin F., Il'inskaya O., Harms H. and Kleinsteuber S., Bacteria and archaea involved in anaerobic digestion of distillers grains with solubles. Applied Microbiology and Biotechnology, 89, 2039-2052 (2011).

79. Kampmann K., Ratering S., Kramer I., Schmidt M., Zerr W. and Schnell S., Unexpected stability of Bacteroidetes and Firmicutes communities in laboratory biogas reactors fed with different defined substrates. Applied and environmental microbiology, 78, 2106-2119 (2012).

80. Sousa D.Z., Pereira M.A., Alves J.I., Smidt H., Stams A.J.M. and Alves M.M., Anaerobic microbial LCFA degradation in bioreactors. In: Water Science and Technology, pp. 439-444 (2008).

81. Sousa D.Z., Pereira M.A., Stams A.J.M., Alves M.M. and Smidt H., Microbial Communities Involved in Anaerobic Degradation of Unsaturated or Saturated LongChain Fatty Acids. Applied and environmental microbiology, 73, 1054-1064 (2007).

82. Cirne D.G., Paloumet X., Bjornsson L., Alves M.M. and Mattiasson B., Anaerobic digestion of lipid-rich waste - Effects of lipid concentration. Renewable Energy, 32, 965-975 (2007).

83. Wijekoon K.C., Visvanathan C. and Abeynayaka A., Effect of organic loading rate on VFA production, organic matter removal and microbial activity of a two-stage thermophilic anaerobic membrane bioreactor. Bioresource Technology, 102, 5353-5360 (2011).

84. Krakat N., Schmidt S. and Scherer P., Potential impact of process parameters upon the bacterial diversity in the mesophilic anaerobic digestion of beet silage.

Bioresource Technology, 102, 5692-5701 (2011).

85. Montero B., Garcia-Morales J.L., Sales D. and Solera R., Evolution of microorganisms in thermophilic-dry anaerobic digestion. Bioresource Technology, 99, 3233-3243 (2008).

86. Lerm S., Kleybocker A., Miethling-Graff R., Alawi M., Kasina M., Liebrich M. and Wurdemann H., Archaeal community composition affects the function of anaerobic co-digesters in response to organic overload. Waste Management, 32, 389-399 (2012).

87. Karakashev D., Batstone D.J. and Angelidaki I., Influence of Environmental Conditions on Methanogenic Compositions in Anaerobic Biogas Reactors. Applied and Environmental Microbiology, 71, 331-338 (2005).

88. Karakashev D., Batstone D.J., Trably E. and Angelidaki I., Acetate Oxidation Is the Dominant Methanogenic Pathway from Acetate in the Absence of Methanosaetaceae. Applied and environmental microbiology, 72, 5138-5141 (2006).

89. Griffin M.E., McMahon K.D., Mackie R.I. and Raskin L., Methanogenic population dynamics during start-up of anaerobic digesters treating municipal solid waste and biosolids. Biotechnology and Bioengineering, 57, 342-342-355 (1998).

90. Ros M., Franke-Whittle I.H., Morales A.B., Insam H., Ayuso M. and Pascual J.A., Archaeal community dynamics and abiotic characteristics in a mesophilic 
anaerobic co-digestion process treating fruit and vegetable processing waste sludge with chopped fresh artichoke waste. Bioresource Technology, 136, 1-7 (2013).

91. McMahon K.D., Zheng D., Stams A.J.M., Mackie R.I. and Raskin L., Microbial population dynamics during startup and overload conditions of anaerobic digesters treating municipal solid waste and sewage sludge. Biotechnology and Bioengineering, 7, 823-834 (2004).

92. Delbès C., Moletta R. and Godon J.-J., Monitoring of activity dynamics of an anaerobic digester bacterial community using $16 \mathrm{~S}$ rRNA polymerase chain reactionsingle-strand conformation polymorphism analysis. Environmental Microbiology, 2, 506-515 (2000).

93. Demirel B., Yenig, uuml and n O., The Effects of Change in Volatile Fatty Acid (VFA) Composition on Methanogenic Upflow Filter Reactor (UFAF) Performance. Environmental Technology, 23, 1179-1187 (2002).

94. Angelidaki I. and Ahring B.K., Thermophilic anaerobic digestion of livestock waste: the effect of ammonia. Applied Microbiology and Biotechnology, 38, 560-560564 (1993).

95. Angenent L.T., Sung S. and Raskin L., Methanogenic population dynamics during startup of a full-scale anaerobic sequencing batch reactor treating swine waste. Water research, 36, 4648-4654 (2002).

96. Borja R., Sanchez E. and Weiland P., Influence of Ammonia Concentration on Thermophilic Anaerobic Digestion of Cattle Manure in Upflow Anaerobic Sludge Blanket (UASB) Reactors. Process Biochemistry, 31, 477-483 (1996).

97. Buenda I.M., Fernández F.J., Villaseaor J. and Rodraguez L., Feasibility of anaerobic co-digestion as a treatment option of meat industry wastes. Bioresource technology, 100, 1903-1909 (2009).

98. Hansen K.H., Angelidaki I. and Ahring B.K.R., Anaerobic digestion of swine manure: Inhibition by ammonia. Water research, 32, 5-12 (1998).

99. Ripley L.E., Boyle W.C. and Converse J.C., Improved alkalimetric monitoring for anaerobic digestion of high-strength waste. Journal of the Water Pollution Control Federation, 58, Medium: X; Size: Pages: 406 (1986).

100. Calli B., Mertoglu B., Inanc B. and Yenigun O., Methanogenic diversity in anaerobic bioreactors under extremely high ammonia levels. Enzyme and microbial technology, 37, 448-455 (2005).

101. Xia Y., Massé D.I., McAllister T.A., Kong Y., Seviour R. and Beaulieu C., Identity and diversity of archaeal communities during anaerobic co-digestion of chicken feathers and other animal wastes. Bioresource Technology, 110, 111-119 (2011).

102. Calli B., Mertoglu B., Inanc B. and Yenigun O., Community Changes During Start-up in Methanogenic Bioreactors Exposed to Increasing Levels of Ammonia. Environmental Technology, 85-91 (2005). 
103. Chen Y., Cheng J.J. and Creamer K.S., Inhibition of anaerobic digestion process: A review. Bioresource technology, 99, 4044-4064 (2008).

104. Koster I.W. and Lettinga G., Anaerobic digestion at extreme ammonia concentrations. Biological Wastes, 25, $51-59$ (1988).

105. Callander I.J. and Barford J.P., Precipitation, chelation, and the availability of metals as nutrients in anaerobic digestion. I. Methodology. Biotechnology and Bioengineering, 25, 1947-1957 (1983).

106. Callander I.J. and Barford J.P., Precipitation, chelation, and the availability of metals as nutrients in anaerobic digestion. II. Applications. Biotechnology and Bioengineering, 25, 1959-1972 (1983).

107. Murray W.D. and Van Den Berg L., Effects of nickel, cobalt, and molybdenum on performance of methanogenic fixed-film reactors. Applied and environmental microbiology, 42, 502-505 (1981).

108. Hoban D.J. and Van Den Berg L., Effect of Iron on Conversion of Acetic Acid to Methane During Methanogenic Fermentations. Journal of Applied Bacteriology, 47, 153-159 (1979).

109. Raju N.R., Devi S.S. and Nand K., Influence of trace elements on biogas production from mango processing waste in $1.5 \mathrm{~m} 3 \mathrm{KVIC}$ digesters. Biotechnology Letters, 13, 461-464 (1991).

110. Espinosa A., Rosas L., Ilangovan K. and Noyola A., Effect of trace metals on the anaerobic degradation of volatile fatty acids in molasses stillage. Water Science and Technology, 32, 121-129 (1995).

111. Wilkie A., Goto M., Bordeaux F.M. and Smith P.H., Enhancement of anaerobic methanogenesis from napiergrass by addition of micronutrients. Biomass, 11, 135-146 (1986).

112. Jarvis Ã., Nordberg Ã., Jarlsvik T., Mathisen B. and Svensson B.H., Improvement of a grass-clover silage-fed biogas process by the addition of cobalt. Biomass and Bioenergy, 12, 453-460 (1997).

113. Zandvoort M.H., van Hullebusch E.D., Golubnic S., Gieteling J. and Lens P.N.L., Induction of cobalt limitation in methanol-fed UASB reactors. Journal of Chemical Technology and Biotechnology, 81, 1486-1495 (2006).

114. Facchin V., Cavinato C., Fatone F., Pavan P., Cecchi F. and Bolzonella D., Effect of trace element supplementation on the mesophilic anaerobic digestion of foodwaste in batch trials: The influence of inoculum origin. Biochemical Engineering Journal, 70, 71-77 (2013).

115. Zhang Y., Yan L., Chi L., Long X., Mei Z. and Zhang Z., Startup and operation of anaerobic EGSB reactor treating palm oil mill effluent. Journal of Environmental Sciences, 20, 658-663 (2008). 
116. Pobeheim H., Munk B., Johansson J. and Guebitz G.M., Influence of trace elements on methane formation from a synthetic model substrate for maize silage. Bioresource Technology, 101, 836-839 (2010).

117. Kim M., Ahn Y.-H. and Speece R.E., Comparative process stability and efficiency of anaerobic digestion; mesophilic vs. thermophilic. Water Research, 36, 4369-4385 (2002).

118. Jiang Y., Heaven S. and Banks C.J., Strategies for stable anaerobic digestion of vegetable waste. Renewable Energy, 44, 206-214 (2012).

119. Climenhaga M. and Banks C., Anaerobic digestion of catering wastes: effect of micronutrients and retention time. (2008).

120. Zhang L. and Jahng D., Long-term anaerobic digestion of food waste stabilized by trace elements. Waste Management, 32, 1509-1515 (2012).

121. Banks C.J., Zhang Y., Jiang Y. and Heaven S., Trace element requirements for stable food waste digestion at elevated ammonia concentrations. Bioresource Technology, 104, 127-135 (2012).

122. Takashima M., Speece R.E. and Parkin G.F., Mineral requirements for methane fermentation. Critical Reviews in Environmental Control, 19, 465-479 (1990).

123. Demirel B. and Scherer P., Trace element requirements of agricultural biogas digesters during biological conversion of renewable biomass to methane. Biomass and Bioenergy, 35, 992-998 (2011).

124. Fermoso F.G., Collins G., Bartacek J., O'Flaherty V. and Lens P., Acidification of methanol-fed anaerobic granular sludge bioreactors by cobalt deprivation: Induction and microbial community dynamics. Biotechnology and Bioengineering, 99, 49-58 (2008).

125. Deflaun M.F. and Steffan R., Bioaugmentation. In: Encyclopedia of Environmental Microbiology, Bitton G. (ed.), Wiley-Interscience, New York, pp. 434$442(2002)$.

126. Rittmann B.E. and Whiteman R., Bioaugmentation: a coming of age. Water Quality International, 1, 16 (1994).

127. El Fantroussi S. and Agathos S.N., Is bioaugmentation a feasible strategy for pollutant removal and site remediation? Current opinion in microbiology, 8, 268-275 (2005).

128. Gentry T.J., Rensing C. and Pepper I.L., New Approaches for Bioaugmentation as a Remediation Technology. Critical Reviews in Environmental Science and Technology, 34, 447 - 494 (2004).

129. Vogel T.M., Bioaugmentation as a soil bioremediation approach. Current opinion in biotechnology, 7, 311-316 (1996). 
130. Schauer-Gimenez A.E., Zitomer D.H., Maki J.S. and Struble C.A., Bioaugmentation for improved recovery of anaerobic digesters after toxicant exposure. Water Research, 44, 3555-3564 (2010).

131. Satoh H., Okabe S., Yamaguchi Y. and Watanabe Y., Evaluation of the impact of bioaugmentation and biostimulation by in situ hybridization and microelectrode. Water Research, 37, 2206-2216 (2003).

132. Limbergen H.V., Top E.M. and Verstraete W., Bioaugmentation in activated sludge: current features and future perspectives. Applied Microbiology and Biotechnology, 50, 16-23 (1998).

133. Nancharaiah Y.V., Joshi H.M., Hausner M. and Venugopalan V.P., Bioaugmentation of aerobic microbial granules with Pseudomonas putida carrying TOL plasmid. Chemosphere, 71, 30-35 (2008).

134. Westerholm M., Leven L. and Schnuer A., Bioaugmentation of Syntrophic Acetate-Oxidizing Culture in Biogas Reactors Exposed to Increasing Levels of Ammonia. Applied and environmental microbiology, 78, 7619-7625 (2012).

135. Savant D. and Ranade D., Application of Methanobrevibacter acididurans in anaerobic digestion. Water Science and Technology, 50, 109-114 (2004).

136. Savant D.V., Shouche Y.S., Prakash S. and Ranade D.R., Methanobrevibacter acididurans sp. nov., a novel methanogen from a sour anaerobic digester. International Journal of Systematic and Evolutionary Microbiology, 52, 1081-1087 (2002).

137. Hashsham S.A., Fernández A.S., Dollhopf S.L., Dazzo F.B., Hickey R.F., Tiedje J.M. and Criddle C.S., Parallel Processing of Substrate Correlates with Greater Functional Stability in Methanogenic Bioreactor Communities Perturbed by Glucose. Applied and Environmental Microbiology, 66, 4050-4057 (2000).

138. Briones A. and Raskin L., Diversity and dynamics of microbial communities in engineered environments and their implications for process stability. Current opinion in biotechnology, 14, 270-276 (2003).

139. Palatsi J., Laureni M., Andres M.V., Flotats X., Nielsen H.B. and Angelidaki I., Strategies for recovering inhibition caused by long chain fatty acids on anaerobic thermophilic biogas reactors. Bioresource technology, 100, 4588-4596 (2009).

140. Bjerketorp J., Ng Tze Chiang A., Hjort K., Rosenquist M., Liu W.-T. and Jansson J.K., Rapid lab-on-a-chip profiling of human gut bacteria. Journal of Microbiological Methods, 72, 82-90 (2008).

141. Franke-Whittle I.H., Goberna M., Pfister V. and Insam H., Design and development of the ANAEROCHIP microarray for investigation of methanogenic communities. Journal of Microbiological Methods, 79, 279-288 (2009).

142. Sundh I., Carlsson H., Nordberg Ã.k., Hansson M. and Mathisen B., Effects of glucose overloading on microbial community structure and biogas production in a laboratory-scale anaerobic digester. Bioresource technology, 89, 237-243 (2003). 
143. Frostegård A., Tunlid A. and Baath E., Use and misuse of PLFA measurements in soils. Soil Biology and Biochemistry, 43, 1621-1625 (2011).

144. Gattinger A., Günthner A., Schloter M. and Munch J.C., Characterisation of Archaea in Soils by Polar Lipid Analysis. Acta Biotechnologica, 23, 21-28 (2003).

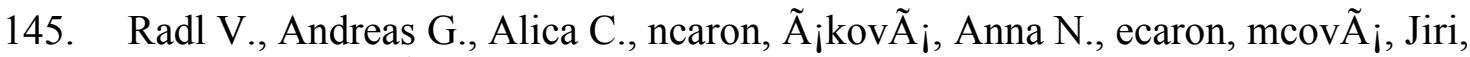
Ccaron, uhel, Miloslav Å i., Jean Charles M., Michael S. and Dana E., Effects of cattle husbandry on abundance and activity of methanogenic archaea in upland soils. The ISME Journal, 1, 443-452 (2007).

146. Oravecz O., Elhottova D., Kristufek V., Sustr V., Frouz J., Triska J. and Marialigeti K., Application of ARDRA and PLFA analysis in characterizing the bacterial communities of the food, gut and excrement of saprophagous larvae of Penthetria holosericea (Diptera: Bibionidae): a pilot study. Folia Microbiol, 49, 83-93 (2004).

147. Schwarzenauer T. and Illmer P., PLFA profiles for microbial community monitoring in anaerobic digestion. Folia Microbiologica, 57, 331-333 (2012).

148. Buyer J.S. and Sasser M., High throughput phospholipid fatty acid analysis of soils. Applied Soil Ecology, 61, 127-130 (2012).

149. McMahon K.D., Martin H.G. and Hugenholtz P., Integrating ecology into biotechnology. Current Opinion in Biotechnology, 18, 287-292 (2007).

150. Xu Q., Gao W., Ding S.-Y., Kenig R., Shoham Y., A.Bayer E. and Lamed R., The Cellulosome System of Acetivibrio cellulolyticus Includes a Novel Type of Adaptor Protein and a Cell Surface Anchoring Protein. Journal of Bacteriology, 185, 4548-4557 (2003).

151. Suen G., Stevenson D.M., Bruce D.C., Chertkov O., Copeland A., Cheng J.-F., Detter C., Detter J.C., Goodwin L.A., Han C.S., Hauser L.J., Ivanova N.N., Kyrpides N.C., Land M.L., Lapidus A., Lucas S., Ovchinnikova G., Pitluck S., Tapia R., Woyke T., Boyum J., Mead D. and Weimer2 P.J., Complete Genome of the Cellulolytic Ruminal Bacterium Ruminococcus albus 7. Journal of Bacteriology, 193, 5574-5575 (2011).

152. Shin S.G., Han G., Lim J., Lee C. and Hwang S., A comprehensive microbial insight into two-stage anaerobic digestion of food waste-recycling wastewater. Water Research, 44, 4838-4849 (2010).

153. Ariesyady H.D., Ito T. and Okabe S., Functional bacterial and archaeal community structures of major trophic groups in a full-scale anaerobic sludge digester. Water Research, 41, 1554-1568 (2007).

154. Ariesyady H., Ito T., Yoshiguchi K. and Okabe S., Phylogenetic and functional diversity of propionate-oxidizing bacteria in an anaerobic digester sludge. Applied Microbiology and Biotechnology, 75, 673-683 (2007).

155. Sekiguchi Y., Kamagata Y., Nakamura K., Ohashi A. and Harada H., Syntrophothermus lipocalidus gen. nov., sp. nov., a novel thermophilic, syntrophic, 
fatty-acid-oxidizing anaerobe which utilizes isobutyrate. International Journal of Systematic and Evolutionary Microbiology, 50, $771-779$ (2000).

156. Sekiguchi Y., Yamada T., Hanada S., Ohashi A., Harada H. and Kamagata Y., Anaerolinea thermophila gen. nov., sp. nov. and Caldilinea aerophila gen. nov., sp. nov., novel filamentous thermophiles that represent a previously uncultured lineage of the domain bacteria at the subphylum level. International Journal of Systematic and Evolutionary Microbiology, 53, 1843-1851 (2003).

157. Yamada T., Imachi H., Ohashi A., Harada H., Hanada S., Kamagata Y. and Sekiguchi Y., Bellilinea caldifistulae gen. nov., sp. nov and Longilinea arvoryzae gen. nov., sp. nov., strictly anaerobic, filamentous bacteria of the phylum Chloroflexi isolated from methanogenic propionate-degrading consortia. International Journal of Systematic and Evolutionary Microbiology, 57, 2299-2306 (2007).

158. Yamada T. and Sekiguchi Y., Cultivation of uncultured Chloroflexi subphyla: Significance and ecophysiology of formerly uncultured Chloroflexi 'subphylum i' with natural and biotechnological relevance. Microbes and Environments, 24, 205-216 (2009).

159. Ganidi N., Tyrrel S. and Cartmell E., Anaerobic digestion foaming causes "A review". Bioresource Technology, 100, 5546-5554 (2009).

160. Nielsen P.H., Kragelund C., Seviour R.J. and Nielsen J.L., Identity and ecophysiology of filamentous bacteria in activated sludge. FEMS Microbiology Reviews, 33, 969-998 (2009).

161. Rossetti S., Tomei M.C., Nielsen P.H. and Tandoi V., Microthrix parvicella, a filamentous bacterium causing bulking and foaming in activated sludge systems: a review of current knowledge. FEMS Microbiology Reviews, 29, 49-64 (2005).

162. Seviour R., Kragelund C., Kong Y., Eales K., Nielsen J. and Nielsen P., Ecophysiology of the Actinobacteria in activated sludge systems. Antonie van Leeuwenhoek, 94, 21-33 (2008).

163. Shen F.-T., Huang H.-R., Arun A.B., Lu H.-L., Lin T.-C., Rekha P.D. and Young C.-C., Detection of filamentous genus Gordonia in foam samples using genusspecific primers combined with PCRÂ â $€$ “" denaturing gradient gel electrophoresis analysis. Canadian Journal of Microbiology, 53, 768-774 (2007).

164. Baena S., Fardeau M.L., Labat M., Ollivier B., Thomas P., Garcia J.L. and Patel B.K.C., Aminobacterium colombiensegen. nov. sp. nov., an Amino Acid-degrading Anaerobe Isolated from Anaerobic Sludge. Anaerobe, 4, 241-250 (1998).

165. Diaz C., Baena S., Fardeau M.-L. and Patel B.K.C., Aminiphilus circumscriptus gen. nov., sp. nov., an anaerobic amino-acid-degrading bacterium from an upflow anaerobic sludge reactor. International Journal of Systematic and Evolutionary Microbiology, 57, 1914-1918 (2007).

166. Menes R.J. and Muxí L., Anaerobaculum mobile sp. nov., a novel anaerobic, moderately thermophilic, peptide-fermenting bacterium that uses crotonate as an 
electron acceptor, and emended description of the genus Anaerobaculum. International Journal of Systematic and Evolutionary Microbiology, 52, 157-164 (2002).

167. Vartoukian S.R., Palmer R.M. and Wade W.G., The division "Synergistes". Anaerobe, 13, 99-106 (2007).

168. Nielsen H.B., Mladenovska Z. and Ahring B.K., Bioaugmentation of a two-stage thermophilic $\left(68^{\circ} \mathrm{C} / 55^{\circ} \mathrm{C}\right)$ anaerobic digestion concept for improvement of the methane yield from cattle manure. Biotechnology and Bioengineering, 97, 1638-1643 (2007).

169. Costa J.C., Barbosa S.G., Alves M.M. and Sousa D.Z., Thermochemical preand biological co-treatments to improve hydrolysis and methane production from poultry litter. Bioresource Technology, 111, 141-147 (2012).

170. Cavaleiro A.J., Sousa D.Z. and Alves M.M., Methane production from oleate: Assessing the bioaugmentation potential of Syntrophomonas zehnderi. Water Research, 44, 4940-4947 (2010).

171. Cirne D.G., Björnsson L., Alves M. and Mattiasson B., Effects of bioaugmentation by an anaerobic lipolytic bacterium on anaerobic digestion of lipidrich waste. Journal of Chemical Technology \& Biotechnology, 81, 1745-1752 (2006).

172. Tale V.P., Maki J.S., Struble C.A. and Zitomer D.H., Methanogen community structure-activity relationship and bioaugmentation of overloaded anaerobic digesters. Water Research, 45, 5249-5256 (2011).

173. Saravanane R., Murthy D.V.S. and Krishnaiah K., Bioaugmentation and anaerobic treatment of pharmaceutical effluent in fluidized bed reactor. Journal of Environmental Science and Health, Part A, 36, 779-791 (2001).

174. Allison S.D. and Martiny J.B.H., Resistance, resilience, and redundancy in microbial communities. Proceedings of the National Academy of Sciences, 105, 1151211519 (2008). 